\title{
Metropolitan USA: Evidence from the 2010 Census
}

\author{
John Rennie Short \\ Department of Public Policy, University of Maryland Baltimore County, 1000 Hilltop Circle, Baltimore, MD 21250, USA
}

Correspondence should be addressed to John Rennie Short, jrs@umbc.edu

Received 27 November 2011; Accepted 14 March 2012

Academic Editor: Shirlena Huang

Copyright ( 12012 John Rennie Short. This is an open access article distributed under the Creative Commons Attribution License, which permits unrestricted use, distribution, and reproduction in any medium, provided the original work is properly cited.

I will review the major changes in the distribution of the metropolitan population of the United States (US), as revealed by the 2010 data recently released by the US Census. These data allow us to track recent changes and provide the basis for a discussion of longer-term trends identified in previous studies of US cities (Short 2006, 2007) and the city suburban nexus (Hanlon et al. 2010). In brief summary, the paper will show the continuing metropolitanization and suburbanization of the US population. A more nuanced picture will reveal evidence of stress in suburban areas and population resurgence in selected central city areas. Overall, the story is one of a profound revalorization and a major respatialization of the US metropolis.

\section{The Broad Picture}

The mean center of the US mainland population is plotted for each Census decade since 1790. The point marks the central fulcrum of the national population. In 1790 the mean center was located in Maryland and over the years has steadily moved westward in line with the westward shift of population. Between 1970 and 1980, the mean center crossed the Mississippi River, and by 2000 it was located in Phelps County Missouri. By 2010, it shifted further westwards and southward to Texas County in Missouri. The slow, steady shift of the mean center marks the redistribution of the US population to the expanding metro areas of the South and West. Its slow progress, however, reminds us of the continuing population weight of the Northeast.

The mean population center now passes through the interior of the country, the so-called heartland. Yet it is a heart with an anemic demographic beat. The population of six counties in this region-Fayette, Marion, Randolph, and Shelby in Illinois and Montgomery and Dent in Missouriwas 144,880 in 1950 , rising to only 145,309 in 2010 . In much of the rural interior of the US, the story is one of continuing relative population decline as the people move to the city regions. The county that hosted the mean center of population in 2010-Texas County, Missouri-saw only slight population increase from 18,992 in 1950 to 26,008 in 2010. The percentage of persons in the county living below the poverty rate was 24.4 percent in 2010 -almost double the national average-and the median household income was only three-fifths of the national average. The rural heartland is losing population and experiencing economic stress.

\section{Continuing Metropolitanization}

The drift of population to large cities continues. The US census employs the term metropolitan statistical area (MSA) to refer to urban areas with a core area of at least 50,000 and economic links to surrounding counties. Using this statistical, rather than political division of municipal boundaries, it is possible to measure the metropolitanization of the US population. In 1950 the metropolitan population was just over a half at 56.1 percent of the total US population. By 2010 the figure was 83.6. The US population is increasingly and overwhelmingly concentrated in metropolitan areas. More than 90 percent of the country's entire population growth in the last decade occurred within MSAs.

A further 10 percent of the US population lives in micropolitan statistical areas, which contain an urban core of at least 10,000 and, in total, have less than 50,000 population. Only 6.3 percent (versus 6.8 percent in 2000) live outside these two types of urban areas. The US continues to become a more urban and metropolitan society. 
When we break down the metropolitan areas by size, there are differential growth rates. Table 1 shows the population for different sized MSAs from 1980 to 2010. The greatest growth was concentrated in the smaller sized metro areas. The steady growth of the largest, that is, greater than 5 million population, MSAs, from 1980 to 2000, is now eclipsed by the increasing growth rate of the smaller sized MSAs. This is partly a function of reclassification as smaller urban areas become classified as MSAs but also perhaps indicative of a greater spread of economic activity and population down the hierarchy of MSAs.

Table 2 lists the twenty largest MSAs from 1950 to 2010. Notice the stability at the very top of the hierarchy with New York, Los Angeles, Chicago, Boston and Philadelphia and San Francisco keeping their position in the top ten over this 60year period. There is also change as Sunbelt metro areas enter the top twenty. There were six metro areas in 2010 that were not part of the top twenty in 1950-Atlanta, Dallas, Denver, Orlando, Sacramento, and San Juan. The inclusion of San Juan, in Puerto Rico, now involves a wider definition of the "national" urban system than one restricted to mainland USA.

\section{Central Cities}

The metropolitan region can be divided into central city and suburban areas. The most significant feature of the last sixty years is the suburbanization of the US population. In 1950 only 23 percent of the US population was living in suburbs. This figure increased to 46.8 percent in 2010 . The central city population has remained relatively fixed at around one-third of the entire population. In 2010 it was 36.9 percent.

The story of the central city of MSAs is complex. Short and Mussman (forthcoming) plot the individual trajectory of the population size at each successive Census since 1900 of the top 100 cities and identify four model types. The first type of city is steady decline. A typical city in this category is Detroit that experienced a peak of 1.84 million around midtwentieth century and then continuous decline; its 2010 population was 713,777 down from 951,270 in 2000. The city embodies the rise and rapid fall of the older, underbounded, industrial city. Other cities in this category include Akron, Baltimore, Birmingham, Buffalo, Cincinnati, Cleveland, New Orleans, Rochester, Toledo, and Pittsburgh. In these cities the loss of employment caused by the long slow decline of manufacturing is yet to be replaced completely by new forms of economic growth. These cities also bear the brunt of an urban fiscal crisis as the steady loss of population and tax base erodes the revenues of the city. The second type of city is continuous increase. Here the story is of rising economic and population growth and ease of annexation. A typical case is San Jose, CA, a Sunbelt city with an expanding economy based largely on information technology. In 1950 the city population was only 95,280, but by 2010 it was 945,942 . Decades of spectacular growth fueled in particular by the Silicon Valley boom in hightechnology and computer-related industries make San Jose one of the most prosperous and economically dynamic cities

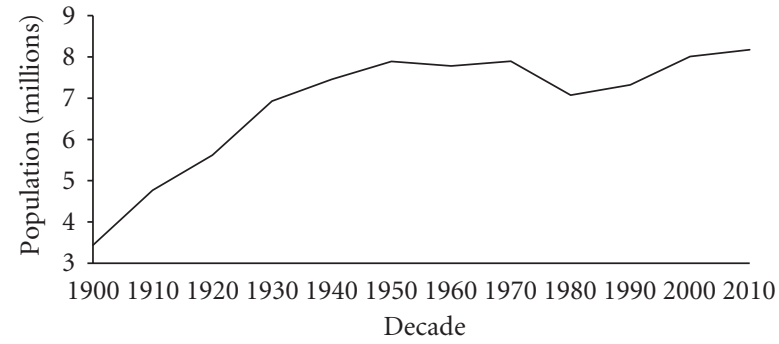

Figure 1: Population of New York City.

in the country. In 2010, San Jose's median household income was $\$ 76,794$, compared to the national median household income of $\$ 50,046$. The city was also able to annex territory, increasing its area size from 17 square miles in 1950 to 177 in 2010. Other examples of this type include San Diego, CA, Las Vegas, NV, and Orlando, FL. The third model type is growth interrupted. Here examples include New York City (NYC), Atlanta, San Francisco, and Seattle. These cities' upward population trajectory saw some decline before returning to growth and eventually surpassing their previous population peak. Figure 1 plots the trajectory of New York City where the population was relatively flat from 1950 to 1970 before a 20-year decline and then resurgence after 1990. The city's areal size remained constant at 303 square miles from 1950 to 2010. In Atlanta, there was rapid growth from 1950 to 1970 followed by 30 years of decline before population began to up tick again after 2000. In the case of Seattle, population peaked in 1960 then declined before growth returned by the 1990 census. The city was the same size in 2010 - 84 square miles-as it was in 1960. In this category some annexations did occur, but, especially for the large cities of Atlanta, New York, San Francisco, and Seattle, population growth within stable boundaries was the most important process.

Then there is the slowly resurgent city, where previous peaks are not reached, but there is a slow steady return of population. Examples include Boston, Philadelphia, and Washington, DC. In all three cases the areal size of the city remained roughly the same. Washington DC's population peaked in 1950, then saw continuous decline until 2000 at which point the city's population began a decade-long resurgence. Cities of this type are big urban areas that did not reach the free fall of continuous decline nor the pronounced returned upward trajectory of the growth-interrupted cities. These cities show signs of population recovery, if not quite to past peaks, at least a bending of the curve from decline to upswing. And in most cases, population growth was not simply the result of city annexation of suburban territory.

The four categories are model types, and there is some overlap between the categories. Chicago, IL, for example, lost considerable population from 1950 to 1990, gained over 100,000 between 1990 and 2000, then lost 20,000 between 2000 and 2010 all against a background of fixed areal size since 1960. It falls between steadily declining and resurgent city categories. Other cities in this same liminal categorical space are Philadelphia, PA, and St. Paul, MN. Some cities are located in the continuous growth category despite some 
TABLE 1: Percentage of US population in metropolitan areas (MSAs), 1980-2010.

\begin{tabular}{lcccc}
\hline MSA size & 1980 & 1990 & 2000 & 2010 \\
\hline Over 5 million & 20.4 & 21.1 & 29.9 & 24.6 \\
1 up to 5 million & 25.2 & 28.9 & 27.6 & 29.5 \\
Up to 1 million & 29.2 & 27.5 & 22.9 & 29.5 \\
Nonmetro areas & 25.2 & 22.5 & 19.6 & 16.4 \\
\hline Total & 100 & 100 & 100 & 100 \\
\hline
\end{tabular}

small reductions from 2000 to 2010; these include Hialeah, FL, St. Petersburg, FL, Santa Ana, CA, and Tulsa, OK.

Some of the causes of population resurgences include the growing concentration of high-paying professional jobs in central cities, shrinking US household size that makes suburbs less attractive choices compared to central cities, changing immigration patterns as streams of foreign-born migrants move to central cities. Mikelbank $[1,2]$ highlights some of the trajectories of change within metro regions and between suburban places. Declining crime rates also make central city living a more attractive proposition. There is also a marked uptick in commercial and residential reinvestment in selected central city areas. Selected central city areas are being revalorized as capital and people move back to the city.

The relative position of individual cities is shown in Table 3 that lists the relative size of the largest 20 cities from 1950 to 2010. Two trends can be noted. First, the relative stability of the very largest cities of New York, Los Angeles, Chicago, and Philadelphia that remain within the top ten. Second, the reshuffling of the top twenty as the older industrial areas such as Cleveland, St. Louis, and Buffalo drop out and the more rapidly growing Sunbelt cities such as Houston, San Antonio, Houston, Dallas, and San Jose enter. From 2000 to 2010 three more Sunbelt cities entered the top twenty: Fort Worth, Charlotte, and El Paso. And two rustbelt cities-Baltimore and Milwaukee-dropped out. The changes in rankings embody deeper economic restructuring in the US economy and the associated rise and fall in urban fortunes.

\section{Suburban Areas}

The suburban spread of population continues across the country. Between 2000 and 2010 most MSAs added suburban counties to their metropolitan region. The Pittsburgh MSA, for example, added Armstrong County with a population of 68,941 . More dynamic MSAs significantly extended their metropolitan range of influence even further. Atlanta MSA, for example, added 8 new counties with a combined population of almost 160,000 and total area of 2,250 square miles. The suburban frontier continues its outward movement turning even more of the US landscape into a metropolitan society.

There is considerable variation within the category of suburbs [1]. Hanlon et al. [3] describe the US suburbs as a place of disparate and divergent realities. At one extreme is what Lang and LeFurgy [4] describe as boomburbs that they characterize as municipalities of more than 100,000 that were not the major city of their MSA and experienced double-digit growth for three consecutive decades. Remember, however, that the data reflects different definitions of municipalities. Using 2000 data these authors identified 54 boomburbs with a combined population of 8.9 million. Using the same criteria but updated with 2010 data, only 31 boomburbs were identified with a combined population of approximately 6 million. The rate of red-hot growth has dipped as economic recession, and housing market collapse has undercut very rapid suburban growth. Even the experience of particular boomburbs has slumped since the housing market collapse. Flagler County in Florida, part of the Palm Coast MSA, grew an astonishing 92 percent between 2000 and 2010, a function of the housing boom of 2001-2007. Since 2008 however the housing market has collapsed with rising unemployment and foreclosure rates. The poverty rate in the country has increased by almost fifty percent from 2000 to 2010 , from 11.3 percent of all persons to 15.1 percent. Across the metropolitan landscape, the growth in the former boomburbs has stalled due to the housing crisis.

At the other extreme, there is also what Hanlon [5] describes as "suburbs in crisis." These are defined as suburbs that witnessed population loss and economic retrenchment. Her analysis was based on 2000 data. We can get a more recent snapshot by updating the story of just one of these suburbs. Dundalk, an industrial suburb in the Baltimore MSA, experienced increased poverty and declining income from 2000 to 2010. The poverty rate for individuals increased from 9.2 percent to 12.4 percent in 2010, while the median household income fell from $\$ 46,035$ to $\$ 45,088$. The older industrial suburbs continue to decline.

Over the past half century, the suburban experience has diverged. The difference between rich and poor suburbs has substantially increased. In the past decade the rapid growth of boomburbs has deflated due to the housing crisis and the difference between rich and poor suburbs widens as poverty continues to rise in the poorer suburbs.

\section{Megalopolis}

We can consider some of the changes within metropolitan areas by considering one case study. One of the largest contiguous areas of metropolitan counties is what Jean Gottmann [6] first identified as Megalopolis, a region spanning 600 miles from north of Richmond in Virginia to just north of Portland in Maine and from the shores of the Northern Atlantic to the Appalachians. A profile of the region from 1950 to 2000 was undertaken by Short [7]. The region now includes the consolidated metropolitan areas of Washington-Baltimore, Philadelphia, New York, and Boston and covers 52,000 square miles. In 2000 the population of this giant urban region was 40.6 million. By 2010 it has increased to 44.6 million with in situ growth and new counties being added because of spreading metropolitan influence. It is the single biggest metropolitan concentration of population. In both 2000 and 2010 it contained just over 14 percent of the entire US population. 
TABLE 2: The twenty largest metropolitan areas in the US by population, 1950-2010.

\begin{tabular}{|c|c|c|c|c|c|}
\hline \multirow{2}{*}{ Rank } & 1950 & 1970 & 1990 & 2000 & 2010 \\
\hline & MSA name & MSA name & MSA name & MSA name & MSA name \\
\hline 1 & $\begin{array}{l}\text { New } \\
\text { York—Northeastern NJ }\end{array}$ & New York, NY & New York (CMSA) & $\begin{array}{l}\text { New York, NY } \\
\text { (CMSA) }\end{array}$ & New York, NY (CSA) \\
\hline 2 & Chicago, IL & $\begin{array}{l}\text { Los Angeles/Long } \\
\text { Beach, CA }\end{array}$ & $\begin{array}{l}\text { Los Angeles, CA } \\
\text { (CMSA) }\end{array}$ & $\begin{array}{l}\text { Los Angeles, CA } \\
\text { (CMSA) }\end{array}$ & $\begin{array}{l}\text { Los Angeles, CA } \\
\text { (CSA) }\end{array}$ \\
\hline 3 & Los Angeles, CA & Chicago, IL & Chicago, IL (CMSA) & Chicago, IL (CMSA) & Chicago, IL (CSA) \\
\hline 4 & Philadelphia, PA & Philadelphia, PA & $\begin{array}{l}\text { Washington, DC } \\
\text { (CMSA) }\end{array}$ & $\begin{array}{l}\text { Washington, DC } \\
\text { (CMSA) }\end{array}$ & $\begin{array}{l}\text { Washington, } \\
\text { DC/Baltimore, (CSA) }\end{array}$ \\
\hline 5 & Detroit, MI & Detroit, MI & $\begin{array}{l}\text { San } \\
\text { Francisco/Oakland, } \\
\text { CA (CMSA) }\end{array}$ & $\begin{array}{l}\text { San } \\
\text { Francisco/Oakland, } \\
\text { CA (CMSA) }\end{array}$ & Boston, MA (CSA) \\
\hline 6 & Boston, MA & San Francisco, CA & $\begin{array}{l}\text { Philadelphia, PA } \\
\text { (CMSA) }\end{array}$ & $\begin{array}{l}\text { Philadelphia, PA } \\
\text { (CMSA) }\end{array}$ & $\begin{array}{l}\text { San Jose/San } \\
\text { Francisco/Oakland, } \\
\text { CA (CSA) }\end{array}$ \\
\hline 7 & San Fran/Oakland, CA & Washington, DC & Boston, MA (CMSA) & Boston, MA (CMSA) & $\begin{array}{l}\text { Dallas/Ft. Worth, TX } \\
\text { (CSA) }\end{array}$ \\
\hline 8 & Pittsburgh, PA & Boston, MA & Detroit, MI (CMSA) & Detroit, MI (CMSA) & $\begin{array}{l}\text { Philadelphia, PA } \\
\text { (CSA) }\end{array}$ \\
\hline 9 & St. Louis, MO & Pittsburgh, PA & Dallas, TX (CMSA) & Dallas, TX (CMSA) & Houston, TX (CSA) \\
\hline 10 & Cleveland, $\mathrm{OH}$ & St. Louis, MO & Houston, TX (CMSA) & Houston, TX (CMSA) & Atlanta, CSA \\
\hline 11 & Washington, DC & Baltimore, MD & Miami, FL (CMSA) & Atlanta, GA (CMSA) & Detroit, MI (CSA) \\
\hline 12 & Baltimore, MD & Cleveland, $\mathrm{OH}$ & Seattle, WA (CMSA) & Miami, FL (CMSA) & Seattle, WA (CSA) \\
\hline 13 & $\begin{array}{l}\text { Minneapolis/St. Paul, } \\
\text { MN }\end{array}$ & Houston, TX & Atlanta, GA (CMSA) & Seattle, WA (CMSA) & $\begin{array}{l}\text { Minneapolis/St. Paul, } \\
\text { MN (CSA) }\end{array}$ \\
\hline 14 & Buffalo, NY & Newark, NJ & $\begin{array}{l}\text { Cleveland, } \mathrm{OH} \\
\text { (CMSA) }\end{array}$ & $\begin{array}{l}\text { Phoenix/Mesa, AZ } \\
\text { (CMSA) }\end{array}$ & Denver, CO (CSA) \\
\hline 15 & Cincinnati, $\mathrm{OH}$ & $\begin{array}{l}\text { Minneapolis/St. Paul, } \\
\text { MN }\end{array}$ & $\begin{array}{l}\text { Minneapolis/St. Paul, } \\
\text { MN (MSA) }\end{array}$ & $\begin{array}{l}\text { Minneapolis/St. Paul, } \\
\text { MN (MSA) }\end{array}$ & Cleveland, $\mathrm{OH}$ (CSA) \\
\hline 16 & Milwaukee, WI & Dallas, TX & San Diego, CA & $\begin{array}{l}\text { Cleveland, } \mathrm{OH} \\
\text { (CMSA) }\end{array}$ & St. Louis, MO (CSA) \\
\hline 17 & Kansas City, MO & Seattle, WA & St. Louis, MO & San Diego, CA & Orlando, FL (CSA) \\
\hline 18 & Houston, TX & Anaheim, CA & Pittsburgh (MSA) & St. Louis, MO & San Juan, PR (CSA) \\
\hline 19 & Providence, RI & Milwaukee, WI & San Juan, PR (CMSA) & Denver, CO (CMSA) & $\begin{array}{l}\text { Sacramento, CA } \\
\text { (CSA) }\end{array}$ \\
\hline 20 & Seattle, WA & Atlanta, GA & $\begin{array}{l}\text { Phoenix/Mesa, AZ } \\
\text { (CMSA) }\end{array}$ & San Juan, PR (CMSA) & Pittsburgh, PA (CSA) \\
\hline
\end{tabular}

Bold denotes new to the top twenty. CMSA: combined metropolitan statistical area. CSA: combined statistical area.

Within this region three trends can be noted from 2000 to 2010. First, the urban core regions have retained their relative demographic position. In 2000 the combined population of Boston, New York, Philadelphia, and Washington was 10.64 million and by 2010 this increased to 10.88 million. All these cities had established producer services, while Baltimore, with a relatively large manufacturing base, declined from 651,154 in 2000 to 620,961 in 2010 , reflecting the broader continuing shift of the dynamics of the US economy away from manufacturing to producer services.

Second, suburban dominance continued as the percentage of the regions' total population increased from 72 to 74 percent. Compared to earlier decades, however, the central city-suburban distribution now seems more stable as the years of rapid suburban growth and central city decline are now replaced by a more varied picture of resurgence in selected city centers with a leveling off in rapid suburban increases. There are still areas of rapid growth especially in the southern part of Megalopolis that includes counties fringing the Washington Baltimore MSAs. Loudon County in the northern Virginia suburbs of the Washington MSA, for example, saw an absolute increase from 169,599 in 2000 to 312,311 in 2010. Elsewhere in this particular growth region, rapid growth slowed. Howard County, Maryland, for example, saw a huge population increase from 23,110 in 1950 to 247,842 in 2000 but only a slight increase to 287,085 by 2010 . The growth was effectively a filling-in of the commuting corridor between Washington DC and Baltimore. Many of the former high growth suburbs are now built out. Throughout the region there was also evidence of decline in some of the older inner suburbs, what Puentes and Warren [8] describe as first suburbs. In Essex County in New 
TABLE 3: Twenty largest metropolitan cities in the US by population, 1950-2010.

\begin{tabular}{|c|c|c|c|c|c|}
\hline \multirow{2}{*}{ Rank } & 1950 & 1970 & 1990 & 2000 & 2010 \\
\hline & City name & City name & City name & City name & City name \\
\hline 1 & New York, NY & New York, NY & New York, NY & New York, NY & New York, NY \\
\hline 2 & Chicago, IL & Chicago, IL & Los Angeles, CA & Los Angeles, CA & Los Angeles, CA \\
\hline 3 & Philadelphia, PA & Los Angeles, CA & Chicago, IL & Chicago, IL & Chicago, IL \\
\hline 4 & Los Angeles, CA & Philadelphia, PA & Houston, TX & Houston, TX & Houston, TX \\
\hline 5 & Detroit, MI & Detroit, MI & Philadelphia, PA & Philadelphia, PA & Philadelphia, PA \\
\hline 6 & Baltimore, MD & Houston, TX & San Diego, CA & Phoenix, AZ & Phoenix, AZ \\
\hline 7 & Cleveland, $\mathrm{OH}$ & Baltimore, MD & Detroit, MI & San Diego, CA & San Antonio, TX \\
\hline 8 & St. Louis, MO & Dallas, TX & Dallas, TX & Dallas, TX & San Diego, CA \\
\hline 9 & Washington, DC & Washington, DC & San Antonio, TX & $\begin{array}{l}\text { Louisville-Jefferson } \\
\text { Co, KY }\end{array}$ & Dallas, TX \\
\hline 10 & Boston, MA & Cleveland, $\mathrm{OH}$ & Phoenix, AZ & San Antonio, TX & San Jose, CA \\
\hline 11 & San Francisco, CA & Indianapolis, IN & San Jose, CA & Detroit, MI & Jacksonville, FL \\
\hline 12 & Pittsburgh, PA & Milwaukee, WI & Baltimore, MD & San Jose, CA & Indianapolis, IN \\
\hline 13 & Milwaukee, WI & San Francisco, CA & Indianapolis, IN & Indianapolis, IN & San Francisco, CA \\
\hline 14 & Houston, TX & San Diego, CA & San Francisco, CA & San Francisco, CA & Austin, TX \\
\hline 15 & Buffalo, NY & San Antonio, TX & Columbus, $\mathrm{OH}$ & Jacksonville, FL & Columbus, $\mathrm{OH}$ \\
\hline 16 & New Orleans, LA & Boston, MA & Jacksonville, FL & Columbus, $\mathrm{OH}$ & Fort Worth, TX \\
\hline 17 & Minneapolis, MN & Memphis, TN & Milwaukee, WI & Austin, TX & Charlotte, NC \\
\hline 18 & Cincinnati, $\mathrm{OH}$ & St. Louis, MO & Memphis, TN & Baltimore, MD & Detroit, MI \\
\hline 19 & Seattle, WA & New Orleans, LA & Washington, DC & Memphis, TN & El Paso, TX \\
\hline 20 & Kansas City, MO & Phoenix, AZ & Boston, MA & Milwaukee, WI & Memphis, TN \\
\hline
\end{tabular}

Bold denotes new to the top twenty.

Jersey, for example, population declined from 793,633 in 2000 to 783, 969 in 2010. In Camden New Jersey the decline was from 79,904 to 77,344 and 38 percent people were defined as living below the poverty level, a slight increase from the 2000 figure of 35 percent. A powerful selective outmigration is worsening the situation. Across the suburban landscape, the divergent experience is easily captured by comparing the affluent suburb of Chevy Chase in Maryland with the poor inner suburbs of Camden in New Jersey. The former saw its median household income rise from $\$ 99,520$ in 2000 to $\$ 137,500$ in 2010 , while the latter saw the same figure decline from $\$ 25,418$ to $\$ 23,421$.

Third, Megalopolis, like other large city regions across the country, continues to be a place of increasing racial diversity. In the four combined MSAs that make up this extended region, the percentage of Blacks, Asians, and Hispanics are, respectively, 20.2, 8.9, and 18.6. The respective figures for the US are 12.6, 4.8, and 16.3. Megalopolis is one the most racially diverse regions of the country. The suburban spread of racial minorities is also becoming more marked. The number of Hispanics living in the suburbs of New York MSA increased from 1.69 million in 2000 to 2.39 million in 2010; as a percentage of the total suburban population they increased from 12.8 percent to 17 . In some metro areas there are more minorities living in the suburbs than in the central city. In the Washington DC MSA, for example, there were 857.380 Hispanics living in the suburbs compared to only 54,749 living in the city. The Hispanic experience in
Washington MSA is predominantly a suburban one. Across the entire region, the suburbs are becoming more racially diverse.

Megalopolis is home to significant amounts of immigration from overseas. The foreign born population has increased from 10 percent in 1960 to 23.8 percent in 2010, almost double the national average of 12.4 percent. Migrants are found in both central cities and in suburban areas; particular concentrations can be identified as immigrant gateways. One example is Tyson's Corner, VA, an archetypal edge city located off the Washington DC Beltway. The population of Tyson's Corner is 19,627 with almost 35 percent foreignborn. Immigrant suburbs are now an important part of metropolitan US [9].

\section{Conclusions}

What underlies and embodies these population trends is a profound revalorization and respatialization of the metropolis. From the immediate post-World War II to around 1980, there was massive public and private investment in the suburban fringes. Capital investment was fixed into the suburban landscapes in the form of houses, roads, factories, stores, and infrastructure. From 1950 to around the mid1970s, the primary dynamic of the US metropolis was a suburban shift. But, since the 1970s, there is a revalorization into a new metropolitan form marked by complex patterns 
of growth and decline, expansion and contraction. Knox [10] writes of the "restless urban landscape." This dynamic consists of at least four investment/disinvestment waves: reinvestment in selected central cities, disinvestment from certain inner ring of suburban neighborhoods, new rounds of housing investment in affluent neighborhoods, and the decline of formerly boomburbs as the housing market, especially in the newest suburban areas, has collapsed. The net effect of these changes is to create a complex metropolitan picture.

Against a background of continuing urbanization, relentless metropolitanization, and a restless urban landscape, the US metros now exhibits a subtler pattern than the old one of central city decline and suburban growth. Complex patterns of central city resurgence and suburban crisis are now grafted onto this simple picture. The US metropolis is now a more complex and fascinating place than ever before.

\section{References}

[1] B. A. Mikelbank, "A typology of U.S. suburban places," Housing Policy Debate, vol. 15, no. 4, pp. 935-964, 2004.

[2] B. A. Mikelbank, "Neighborhood déjà Vu: classification in metropolitan Cleveland, 1970-2000," Urban Geography, vol. 32, no. 3, pp. 317-333, 2011.

[3] B. Hanlon, J. R. Short, and T. J. Vicino, Cities and Suburbs: New Metropolitan Realities in the US, Routledge, New York, NY, USA, 2010.

[4] R. E. Lang and J. LeFurgy, Boomburbs: The Rise of America's Accidental Cities, Brookings Institution, Washington, DC, USA, 2007.

[5] B. Hanlon, Once The American Dream: Inner ring Suburbs of the Metropolitan United States, Temple University, Philadelphia, Pa, USA, 2010.

[6] J. Gottmann, Megalopolis, Twentieth Century Fund, New York, NY, USA, 1961.

[7] J. R. Short, Liquid City: Megalopolis and The Contemporary Northeast, Resources for the Future, Washington, DC, USA, 2007.

[8] R. Puentes and D. Warren, One-Fifth of America: A Comprehensive Guide to America's First Suburbs, Brookings Institution, Washington, DC, USA, 2006.

[9] T. J. Vicino, B. Hanlon, and J. R. Short, "A typology of urban immigrant neighborhoods," Urban Geography, vol. 32, no. 3, pp. 383-405, 2011.

[10] P. L. Knox, "The restless urban landscape: economic and sociocultural change and the transformation of metropolitan Washington, DC," Annals of Association of American Geographers, vol. 81, no. 2, pp. 181-209, 1991. 


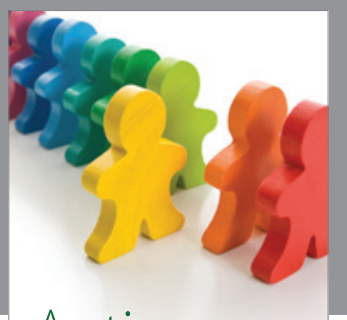

Autism

Research and Treatment
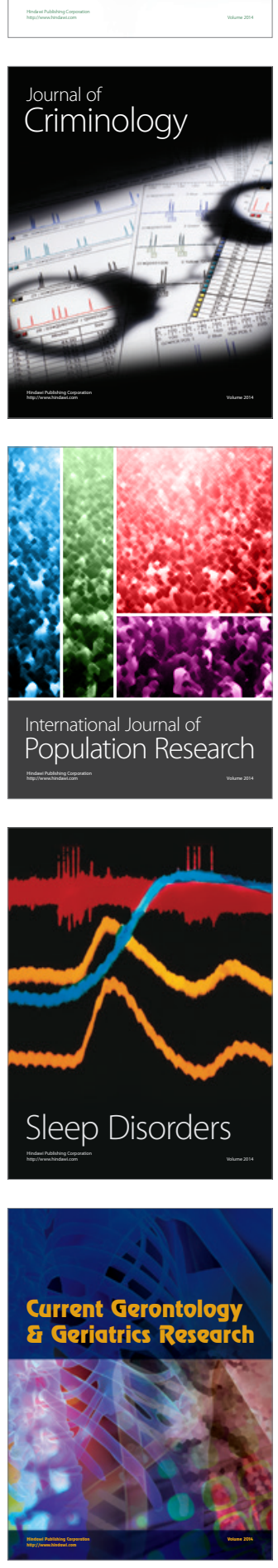
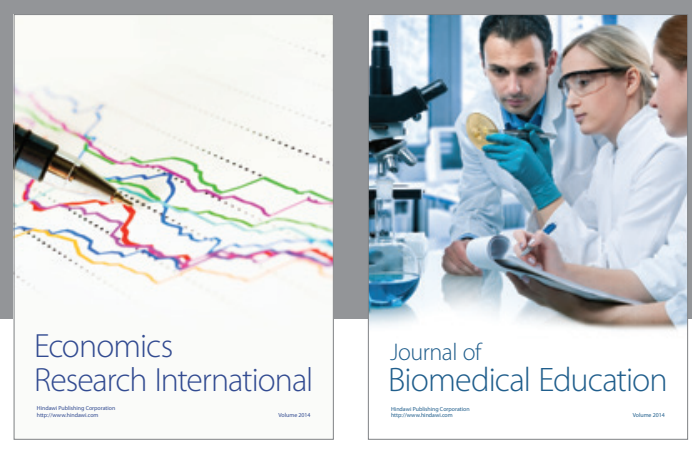

Journal of

Biomedical Education

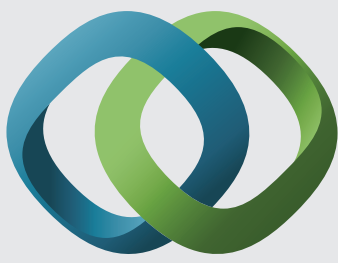

\section{Hindawi}

Submit your manuscripts at

http://www.hindawi.com
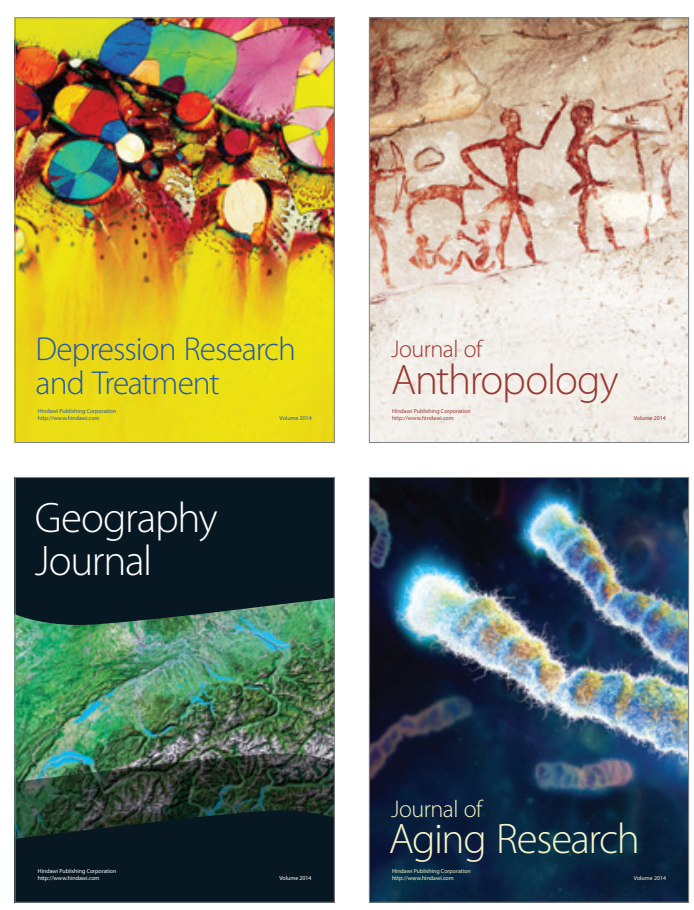

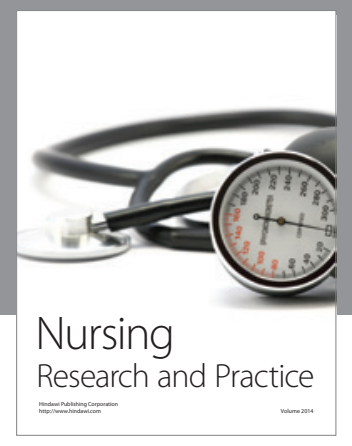

Nursing

Research and Practice

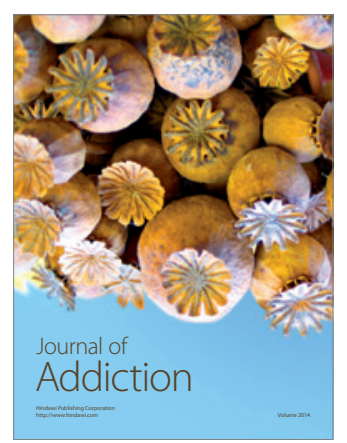

Child Development

Research

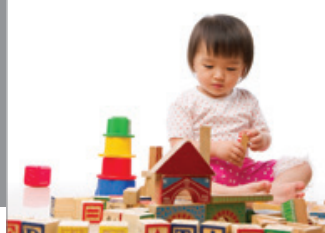

迥
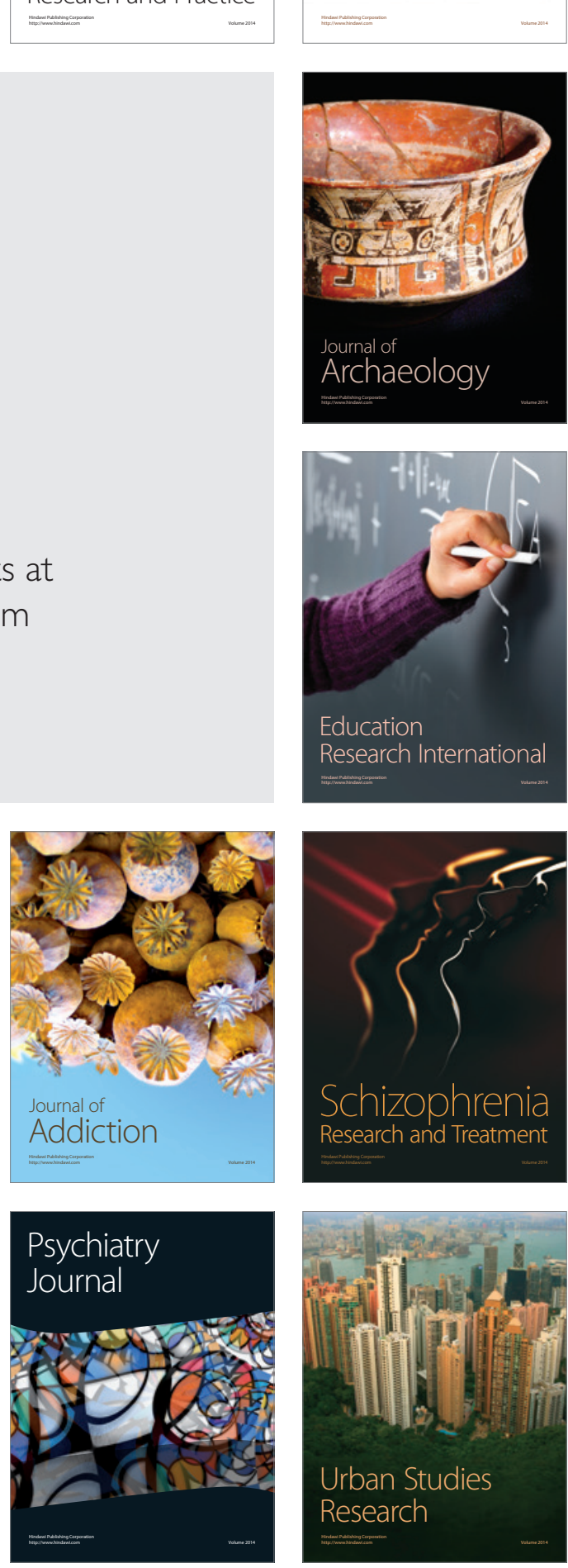